\title{
Factors in the etiopathogenesis of post-adolescent female acne
}

\section{Post-adölesan akneli kadınlarda etiyopatogeneze etki eden faktörler}

\section{Ezgi Özkur, ๑ Damla Demir*, ๑ Illknur Kıvanç Altunay, ๑ Mustafa Demir**, ๑ Oktay Tosun***}

University of Health Sciences Turkey, Șișli Hamidiye Etfal Training and Research Hospital, Clinic of Dermatology, İstanbul, Turkey *University of Health Sciences Turkey, Ümraniye Training and Research Hospital, Clinic of Dermatology; **Clinic of Radiology, İstanbul, Turkey ***University of Health Sciences Turkey, Șișli Hamidiye Etfal Training and Research Hospital, Clinic of Gynecology and Obstetrics, İstanbul, Turkey

\begin{abstract}
Background and Design: Post-adolescent acne has been defined as acne that persists or whose onset starts beyond the age of 25 years. The presence of hyperandrogenemia, polycystic ovary syndrome (PCOS), dyslipidemia, and insulin sensitivity play a role in etiopathogenesis of post-adolescent acne in women as shown in previous studies. This study was conducted to investigate these relationships.

Materials and Methods: We included 45 female patients with post-adolescent acne and 30 age, sex, and body mass index-matched healthy controls. Demographic characteristics, clinical signs of hyperandrogenemia, pelvic ultrasound scan, and hormonal assessment including the [total testosterone (TT), sex hormone binding globulin (SHBG), dehydroepiandrosterone sulfate (DHEAS), follicle stimulating hormone (FSH), luteinizing hormone (LH), prolactin (PRL), estradiol (E2)] and fasting plasma glucose, and insulin and lipid levels were recorded.

Results: Woman with post-adolescent acne had the marked presence of menstrual abnormalities (37.7\%), hirsutism (13.3\%), androgenetic alopecia (11.1\%), metabolic syndrome (MS) (32.4\%), and PCOS (22.2\%). Pelvic ultrasound scans showed that $17.8 \%$ of the patients had polycystic ovaries. In addition, the percentage of current smokers was significantly higher in the patient group than the controls ( $p=0.001)$. TT and LH were significantly higher in post-adolescent acne patients than the controls $(p=0.048$, and $p=0.012$, respectively). No significant differences were observed between patients and controls in terms of SHBG, DHEAS, FSH, PRL, E2, and total cholesterol, low-density lipoprotein cholesterol, high-density lipoprotein cholesterol, and triglyceride levels. No correlations were observed between these parameters and the severity of acne.

Conclusion: Although laboratory hormonal assessment showed no significant difference, post-adolescent acne patients had marked menstrual irregularities, polycystic ovaries, androgenetic alopecia, hirsutism, and MS. However, insulin resistance and dyslipidemia may not play a major role in the pathogenesis of post-adolescent female acne.
\end{abstract}

Keywords: Acne, hyperandrogenemia, polycystic ovary syndrome, dyslipidemia, insulin sensitivity

Öz

Amaç: Post-adölesan akne, 25 yaşından sonra başlayan veya devam eden akne olarak tanımlanmaktadır. Daha önce yapılan çalışmalarda hiperandrojenemi, polikistik over sendromu (PKOS), dislipidemi ve insülin direnci, etiyopatogenezden sorumlu saptanmıştır. Bu çalışma, postadölesan akne hastalarındaki etiyopatogenezi aydınlatmak amacıyla yapılmışır.

Gereç ve Yöntem: Çalışmamıza 45 post-adölesan akneli kadın hasta ve 30 yaş-cinsiyet-vücut kitle indeksi eşlenmiş sağlıkı kontrol dahil edildi. Demografik özellikler, hiperandrojenemi bulguları, pelvik ultrason, serum hormon düzeyleri [total testosteron (TT), seks hormon bağlayan

Address for Correspondence/Yazışma Adresi: Ezgi Özkur MD, University of Health Sciences Turkey, Şişli Hamidiye Etfal Training and Research Hospital, Clinic of Dermatology, İstanbul, Turkey

Phone: +90 5303886781 E-mail: ezgierdal@hotmail.com Received/Geliş Tarihi: 19.04.2020 Accepted/Kabul Tarihi: 11.02.2021 ORCID: orcid.org/0000-0002-9136-7021

Cite this article as: Özkur E, Demir D, Kıvanç Altunay I, Demir M, Tosun O. Factors in the etiopathogenesis of post-adolescent female acne. Turkderm-Turk Arch Dermatol Venereol 2021;55:119-24.

(c) Copyright 2021 by Turkish Society of Dermatology and Venereology

Turkderm - Turkish Archives of Dermatology and Venereology published by Galenos Yayınevi. 
globulin (SHBG), dehidroepiandrosteron sülfat (DHEAS), folikül stimülan hormon (FSH), lüteinizan hormon (LH), prolaktin (PRL), östradiol (E2)], plazma açlık glukozu, insülin ve lipitler değerlendirildi.

Bulgular: Post-adölesan aknesi olan kadın hastalarda menstrüel düzensizlikler (\%37,7), hirsutizm (\%13,3), androgenetik alopesi $(\% 11,1)$, metabolik sendrom $(\% 32,4)$ ve PKOS $(\% 22,2)$ belirgin olarak artmış saptandı. Pelvik ultrasonda hastaların \%17,8'inde overler polikistik görünümde saptandı. Ayrıca sigara içenlerin oranı, kontrol grubuna göre istatistiksel olarak anlamlı yüksekti $(p=0,001)$. Sadece TT ve LH değerleri post-adölesan akne hastalarında istatistik olarak daha yüksek saptandı (sırasıyla; $p=0,048, p=0,012)$. SHBG, DHEAS, FSH, PRL, E2, total kolesterol, LDL-C, HDL-C ve trigliseritlerin düzeyinde hasta veya kontrol grubu arasında fark saptanmadı. Ayrıca akne şiddetiyle bu değerler arasında korelasyon saptanmadı.

Sonuç: Laboratuvar parametrelerinde fark çıkmamakla birlikte; post-adölesan akneli kadın hastalarda artmış menstrüel düzensizlikler, polikistik overler, androgenetik alopesi, hirsutizm ve metabolik sendrom artmış sıklıkta saptanmıştı. Ancak insülin direnci ve dislipidemi post-adölesan akne patogenezinde majör bir rol oynamıyor olabilir.

Anahtar Kelimeler: Akne, hiperandrojenemi, polikistik over sendromu, dislipidemi, insülin direnci

\section{Introduction}

Post-adolescent acne is a term used for persistent adolescent acne or late-onset acne after the age of 25 years. This condition is usually presented with mild-to-moderate inflammatory acne lesions and fewer comedones compared with adolescent acne'. Post-adolescent acne affects $12 \%$ of women and $3 \%$ of men ${ }^{2}$.

Hormonal factors, dietary factors, increased use of cosmetics, and exposure to hot and humid conditions play a role in the etiopathogenesis of post-adolescent acne in women ${ }^{3}$. Post-adolescent acne is more common in women than in men. Thereby, scholars emphasized the underlying hormonal imbalances. However, studies have revealed controversial results about the role of circulating androgen levels or endocrine abnormalities, such as polycystic ovary syndrome (PCOS) or insulin resistance (IR). Given all these considerations, this study aimed to elucidate the factors contributing to the development of post-adolescent acne in women by assessing serum androgens, lipid profiles, the frequency of PCOS, IR, metabolic syndrome (MS), hirsutism, androgenetic alopecia, and menstrual disturbances.

\section{Materials and Methods}

The study included 45 women with post-adolescent acne and age and body mass index [BMl; weight $(\mathrm{kg})$ /height $(\mathrm{m}) 2$ ]-matched 30 healthy controls. Post-adolescent acne was defined as acne that presents in individuals over 25 years old. All participants were evaluated by a standardized form that included demographic data, medical history, cigarette smoking status, disease duration, disease severity, quantity, and the rhythm, theme and, duration of menstruation. A detailed history and examination was carried out for each participant, and associated findings, such as hirsutism and androgenetic alopecia indicating hormonal imbalance, were noted. Acne severity was recorded in accordance with a four-point acne grading system (mild, moderate, moderate-severe, and severe). Patients with endocrine diseases and receiving hormonal therapy, anti-androgens, or systemic isotretionine for at least 3 months before the study were excluded. Ethical clearance for the study was received from the University of Health Sciences Turkey, Şşsli Hamidiye Etfal Training and Research Hospital Institutional Ethical Committee (approval number: 123-456/2019).

All the patients enrolled in the study were called on days 2-3 of their next cycle. Blood samples of peripheral venous blood were drawn after an overnight fasting to investigate the follicle stimulating hormone (FSH), luteinizing hormone (LH), total testosterone (TT), free estradiol (E2), sex hormone binding globulin (SHBG), dehydroepiandrosterone sulfate (DHEAS), prolactin (PRL), fasting blood glucose, fasting insulin, triglyceride (TG), high-density lipoprotein cholesterol (HDL-C) and low-density lipoprotein cholesterol (LDL), cholesterol levels, C-reactive protein (CRP), and erythrocyte sedimentation rate (ESR). Pelvic ultrasound scan was also performed on the same visit for ovarian examination. Polycystic ovary was defined as the presence of $\geq 12$ follicles in each ovary measuring 2-9 $\mathrm{mm}$ in diameter and/or increased ovarian volume $(>10 \mathrm{~mL})$ of at least a single ovary ${ }^{4}$.

The score of $\geq 8$ is considered hirsutism by the modified Ferriman and Gallwey score ${ }^{5}$.

International Federation of Gynecology and Obstetrics classification ${ }^{6}$ was used to characterize menstrual irregularity. The cycle length of 2438 days was considered normal. The diagnosis of MS was based on Adult Treatment Panel III Criteria ${ }^{7}$. The homeostatic model assessment for IR (HOMA-IR) was calculated using this formula: fasting insulin level $(\mu \mathrm{lU} / \mathrm{mL}) \times$ fasting glucose level $(\mathrm{mg} / \mathrm{dL}) / 405$, and IR was defined as an elevated HOMA-IR value of $>2.5^{8}$. PCOS was defined in accordance with the revised 2003 Rotterdam diagnostic criteria ${ }^{4}$.

\section{Statistical Analysis}

Data were analyzed using IBM SPSS 15.0 for Windows v.21.0. (IBM Corp., Armonk, NY). Descriptive statistics are given as the number and percentage for categorical variables and average and standard deviation for numeric variables when appropriate. When parametric assumptions were met, the independent Student's t-test was used to compare numeric variables between patients and controls, and the Mann-Whitney $U$ test was used to compare the numeric variables when parametric assumptions were not met. The chi-square test was used to compare between group differences in categorical variables. Spearman's correlation coefficient was used to analyze the association between numerical variables. The statistical alpha (level of significance) level was accepted as $p<0.05$.

The linear mixed model analysis (percentage of patients with PCOS is the outcome variable) was the main analysis performed, and power analysis suggested that a total minimum sample of 30 individuals for each group was needed based on $p=0.05$, a power of $80 \%$, and an effect size of 0.72 .

\section{Results}

The study included 45 women with post-adolescent acne, aged 30 years, and BMI-matched healthy female controls. The patients' group mean age was 31.1 \pm 5.95 with a $23.98 \pm 3.68$ mean BMI value. The mean disease duration was $60.1 \pm 62.6$ months. A total of $40 \%(n=18)$ of patients had moderate acne severity. Table 1 shows the demographic and clinical findings of the patients and controls. The percentage of 
current smokers in the patient group (54.1\%) was significantly higher than that in the control groups $(40.5 \%, p=0.001)$.

Signs of clinical hyperandrogenism, including history of menstrual irregularities, hirsutism, and androgenetic alopecia, were found in 17 (37.7\%), 6 (13.3\%), and 5 (11.1\%) post-adolescent acne females, respectively, which were higher than the controls. Pelvic ultrasound scans showed that eight acne patients $(17,8 \%)$ had polycystic ovaries, whereas the controls had none. PCOS and MS were found in $22.2 \%$ and $32.4 \%$ of post-adolescent acne patients, respectively.

Table 2 shows the laboratory parameters of patients with postadolescent acne and healthy controls. A statistically significant difference was found in $\mathrm{LH}$ and $\mathrm{TT}$ levels between the patients and controls ( $p=0.012$, and $p=0.048$, respectively). The women with acne had significantly high ESR and CRP levels. Fasting plasma glucose and insulin levels were higher in the control group.

No correlations were observed between severity or disease duration and BMI, HOMA-IR, or any other hormonal measurements, plasma glucose, insulin, and lipid levels in Spearman's correlation ( $p>0.05$ for all comparisons).

\section{Discussion}

The etiopathogenesis of post-adolescent acne remains unclear. Post-adolescent acne is presumed to share similar etiological and pathogenetic features, namely, increased sebum production, ductal hypercornification, inflammation, and increased bacterial activity, with adolescent acne. Other factors were put forward to explain post-adolescent acne; these factors include hormones (mainly hyperandrogenic activity), genetic susceptibility, cosmetics, emotional stress, dietary factors, and resistant bacteria ${ }^{9}$. However, these studies showed conflicted results.

Kligman ${ }^{10}$ previously claimed that adrenal androgen is the major etiopathologic factor in post-adolescent acne. Other studies conducted in previous years reported significantly higher levels of serum testosterone and dihydrotestosterone in adult women

Table 1. Demographic and clinical findings of patients with post-adolescent acne and healthy controls

\begin{tabular}{|c|c|c|c|c|c|}
\hline & \multicolumn{2}{|c|}{ Patients $(n=45)$} & \multicolumn{2}{|c|}{ Controls $(n=30)$} & \multirow[b]{2}{*}{$\mathbf{p}$} \\
\hline & Mean \pm SD & $\begin{array}{l}\text { Min-max } \\
\text { (median) }\end{array}$ & Mean \pm SD & $\begin{array}{l}\text { Min-max } \\
\text { (median) }\end{array}$ & \\
\hline Age (years) & $31.1 \pm 5.95$ & $25-48(30)$ & $32.4 \pm 4.5$ & $26-39(32)$ & 0.111 \\
\hline Height $(\mathrm{cm})$ & $162.8 \pm 6.5$ & $150-190(160)$ & $162.5 \pm 6.5$ & $153-180(161.5)$ & 0.735 \\
\hline Weight (kg) & $63.9 \pm 12.8$ & $47-112(60)$ & $62.9 \pm 11.3$ & $48-85(63)$ & 0.931 \\
\hline $\mathrm{BMI}\left(\mathrm{kg} / \mathrm{m}^{2}\right)$ & $23.98 \pm 3.68$ & $18.3-31.6(23.7)$ & $23.93 \pm 4.72$ & $17.6-36.3(23.6)$ & 0.509 \\
\hline Waist circumference $(\mathrm{cm})$ & $76.7 \pm 13.4$ & $60-114(75.0)$ & $77.5 \pm 13.6$ & $61-108(72)$ & 0.721 \\
\hline Systolic BP (mmHg) & $108.0 \pm 8.8$ & $90-120(110)$ & $103.3 \pm 9.2$ & $90-120(100)$ & 0.032 \\
\hline Diastolic BP (mmHg) & $68.4 \pm 8.3$ & $50-80(70)$ & $72.3 \pm 9.3$ & $60-90(70)$ & 0.088 \\
\hline Disease duration (months) & $60.1 \pm 62.6$ & $3-252(48)$ & - & - & - \\
\hline \multicolumn{6}{|l|}{ Disease severity $\mathrm{n}(\%)$} \\
\hline - Mild & \multicolumn{2}{|l|}{$10(22.2)$} & - & - & - \\
\hline - Moderate & \multicolumn{2}{|l|}{$18(40)$} & - & - & - \\
\hline - Moderate-severe & \multicolumn{2}{|l|}{$12(26.6)$} & - & - & - \\
\hline - Severe & \multicolumn{2}{|l|}{$4(8.8)$} & - & - & - \\
\hline Current smoker n (\%) & \multicolumn{2}{|l|}{$20(54.1)$} & $15(40.5)$ & - & 0.001 \\
\hline Androgenetic alopecia n (\%) & \multicolumn{2}{|l|}{$5(11.1)$} & $0(0)$ & - & * \\
\hline Hirsutism n (\%) & \multicolumn{2}{|l|}{$6(13.3)$} & $2(6.7)$ & - & * \\
\hline Menstrual abnormalities n (\%) & \multicolumn{2}{|l|}{$17(37.7)$} & $2(6.6)$ & - & * \\
\hline - Oligomenorrhea n (\%) & \multicolumn{2}{|l|}{$5(11.1)$} & $0(0)$ & - & * \\
\hline - Menorrhagia n (\%) & \multicolumn{2}{|l|}{$11(24.4)$} & $1(3.3)$ & - & * \\
\hline - Polymenorrhea n (\%) & \multicolumn{2}{|l|}{$2(4.4)$} & $1(3.3)$ & - & * \\
\hline Metabolic syndrome $\mathrm{n}(\%)$ & \multicolumn{2}{|l|}{$12(32.4)$} & $2(5.4)$ & - & * \\
\hline Insulin resistance $\mathrm{n}(\%)$ (HOMA-IR value of $>2.5$ ) & \multicolumn{2}{|l|}{$3(6.7)$} & $6(20)$ & - & * \\
\hline \multicolumn{6}{|l|}{ Ultrasound findings $\mathrm{n}(\%)$} \\
\hline - Simple cyst & \multicolumn{2}{|l|}{$2(4.4)$} & $6(20.0)$ & - & * \\
\hline - Policycstic ovary & \multicolumn{2}{|l|}{$8(17.8)$} & $0(0.0)$ & - & * \\
\hline PCOS n (\%) & \multicolumn{2}{|l|}{$10(22.2)$} & $2(6.7)$ & - & * \\
\hline
\end{tabular}

Minimum, max: Maximum 
with acne compared with healthy controls (Maneschi et al. ${ }^{11}, 70 \%$ Vexiau et al. ${ }^{12}, 86 \%$; Darley et al. ${ }^{13}, 76 \%$; Slayden et al. $\left.{ }^{14}, 55 \%\right)$. On the contrary, several studies showed that serum androgens exhibited no significant increase compared with the age- and sex-matched healthy controls ${ }^{15}$ or were mildly elevated ${ }^{16}$. The following studies revealed inconstant findings. Khunger and $\mathrm{Kumar}^{17}$ studied 280 postadolescent acne patients and observed that clinical features suggestive of hyperandrogenism, such as premenstrual flare (11.7\%), hirsutism (5.7\%), and alopecia (1.8\%), were present, but 7 (3.04\%) women had raised laboratory markers of hyperandrogenism. Sardana et al. ${ }^{18}$ revealed that clinical hyperandrogenism is common in post-adolescent female acne (71.67\%), whereas hyperandrogenemia (TT and DHEAS) was observed in $18.33 \%$ of females. In line with these findings, 3 (6.6\%) patients showed raised laboratory markers of hyperandrogenism and mild elevation in TT levels $(p=0.048)$. LH was significantly higher in acne patients, but the difference between the LH:FSH ratio remained insignificant. On the other hand, androgenetic alopecia (11.1\%), hirsutism (13.3\%), and menstrual irregularities (37\%) were detected more frequently in the patient group than controls. These contrasting findings suggest that not only serum androgen levels can be the main factor in the development of post-adolescent acne in women but also end-organ hypersensitivity, for example, the increased sensitivity of the pilosebaceous unit to androgens may play a role. Numerous studies reported and discussed steroidogenic enzyme activities and their roles in hyperandrogenic states, such as acne, hirsutism, and alopecia ${ }^{19}$. A recent study ${ }^{20}$ showed that women with isolated post-adolescent acne do not have increased levels of adrenal androgens but have similar secretion pattern of 17-hydroxyprogesterone with PCOS patients, suggesting increased enzymatic activity in this pathway.
Considering ovarian factors in female acne, Betti et al. ${ }^{21}$ claimed that although the incidence of classical PCOS was not raised, polycystic ovaries have been reported in $52 \%$ of 46 patients with post-adolescent acne. We observed that eight (17.8\%) patients with post-adolescent acne had polycystic ovaries, whereas the controls had simple cysts. In addition, we detected a higher percentage of PCOS cases (22\%) in post-adolescent acne group than the controls (6.7\%). Another study including 105 women with post-adolescent acne concluded that $65 \%$ of the patients reported worsened acne symptoms during menstruation, which suggests the role of hormonal breakouts in relation to the menstrual cycle ${ }^{22}$. Most of these studies emphasized the importance and incidence of ovarian disorders in post-adolescent acne patients.

Yang et al. ${ }^{23}$ claimed that smoking may be involved in the pathogenesis of post-adolescent acne by increasing the oxidative stress. Similarly, we found a statistically significant difference between groups in terms of the percentage of current smokers $(p=0.001)$.

Balta et al. ${ }^{24}$ found no significant differences in fasting blood glucose, fasting insulin, aspartate aminotransferase, alanine aminotransferase, TG and HDL-C levels, and HOMA-IR index of a similar design with our study, with 35 patients with post-adolescent acne and 35 healthy agesex-BMI-matched control subjects. They claimed that IR may not play a major role in the pathogenesis of post-adolescent acne. We found similar results with no difference in terms of fasting glucose, TC, TG, LDL-C, and HDL-C. Moreover, control patients had higher mean levels of fasting plasma insulin and HOMA-IR index. On the contrary, in another study with 64 patients and 20 healthy controls, the authors reported that adult women with acne had statistically significantly increased levels of TC, TG, and LDL-C compared with the healthy controls and

Table 2. Comparison of laboratory parameters in patients with post-adolescent acne and healthy controls

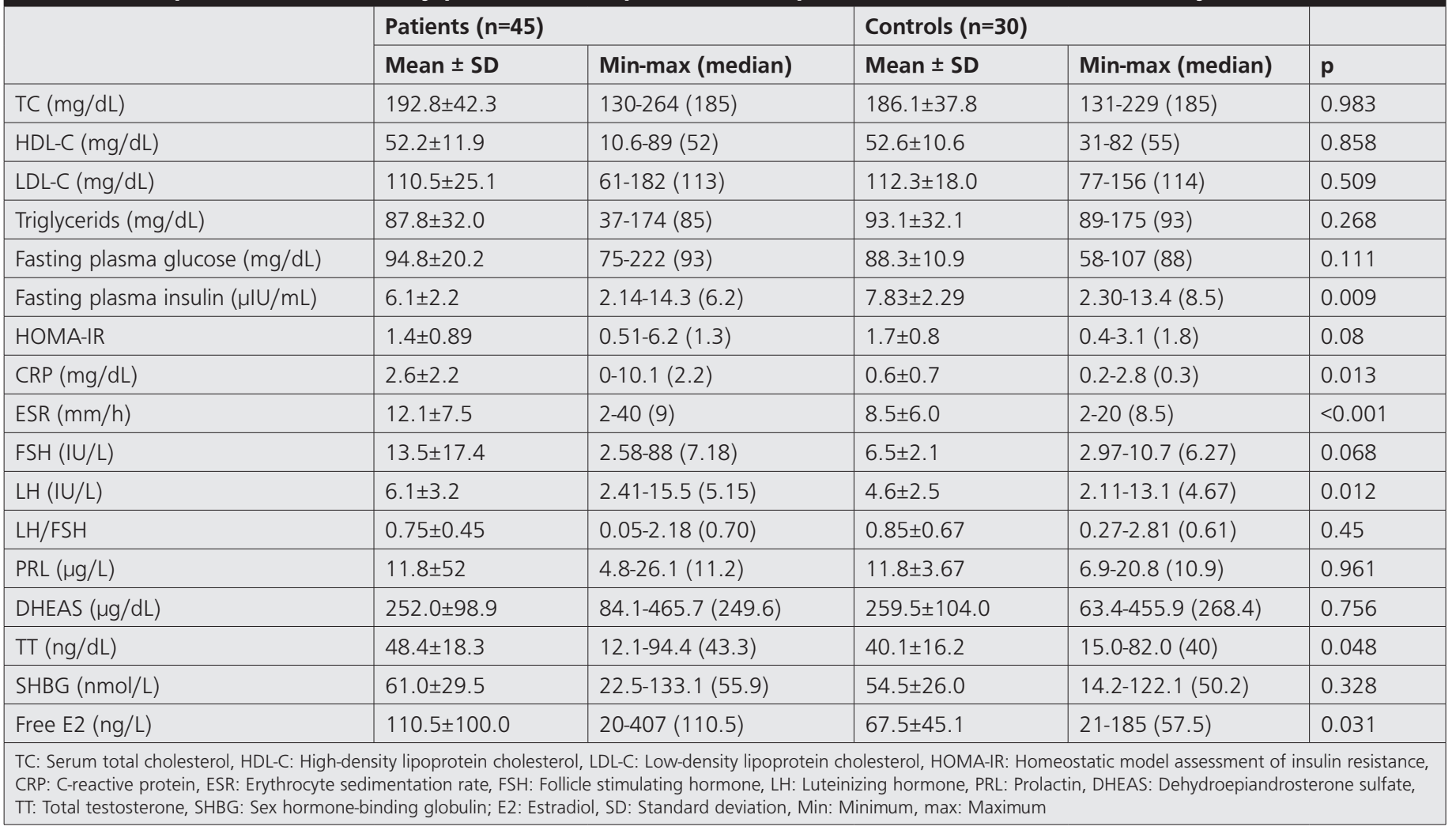


that high-fatty-acid diet may play a role in the pathogenesis of postadolescent acne ${ }^{25}$. El-Akawi et al. ${ }^{26}$ also reported that the increased level of LDL-C is related to severe acne, but they also observed high levels of $\mathrm{TC}$ in obese women. We found no correlation between acne severity or disease duration and plasma lipids. We found a higher percentage of MS cases in post-adolescent acne group (32.4\%) compared with the controls (5.4\%), which may show that not only lipid levels but also MS may be related to post-adolescent acne, which was not studied in previous studies.

Other factors were put forward for the etiopathogenesis of postadolescent acne in literature, but they have not been proven yet. Knaggs et al. ${ }^{27}$ reported that cosmetic usage and occupation are not a significant contributing factor, but on the other hand, $50 \%$ of the post-adolescent acne patients had a first-degree relative with postadolescent acne. In 2018, a study investigated the association between milk intake and post-adolescent acne in 20,416 adults and found no observational or genetic association between milk intake and adult $a^{c} e^{28}$, which have not been reported in observational studies of adolescent acne. In another study with 110 adult acne patients, 37.3\% of patients noticed exacerbation most of the times after intake of oily food $^{29}$. In addition, chronic stress was suggested as a possible cause of increased androgen secretion in several women, resulting in postadolescent $a_{c n} e^{10}$. However, conflicted results have been reported in different studies, that is, $25.7 \% \mathrm{in}^{3}$ the study of Khunger and Kumar ${ }^{17}$; Goulden et al. ${ }^{9}$ reported that $71 \%$ of their acne patients flared with stress. No differences in bacterial flora have been reported between adolescent and adults with acne, and authors suggested that antibioticresistant bacteria and high antibody levels to $P$. acnes are unlikely to be involved in the pathogenesis of post-adolescent acne ${ }^{30}$. In 2012, Vergou et al. ${ }^{31}$ showed that female post-adolescent acne sufferers had significantly higher rates of thyroid autoimmunity compared with the healthy controls.

\section{Study Limitations}

Our study had several limitations. First, we did not include the genetic, dietary, and stressor factors, which may have a role in etiopathogenesis in post-adolescent acne. In addition, regional variations in hormonal values and kit-to-kit variations might have existed. Finally, our patient group had a relatively small number of patients.

\section{Conclusion}

Our study revealed the high frequency of clinical hyperandrogenic features, ovarian abnormalities, and MS in post-adolescent females with acne. However, the laboratory markers of hyperandrogenism, plasma lipids, fasting plasma glucose, and insulin showed no difference between groups. Thus, these factors may not have a major role in the etiopathogenesis of post-adolescent female acne.

\section{Ethics}

Ethics Committee Approval: Ethical clearance for the study was received from the University of Health Sciences Turkey, Şişli Hamidiye Etfal Training and Research Hospital Institutional Ethical Committee (approval number: 123-456/2019).

Informed Consent: Informed consent was obtained.

Peer-review: Externally peer-reviewed.

\section{Authorship Contributions}

Concept: E.Ö., D.D., I.K.A., M.D., O.T., Design: E.Ö., D.D., I.K.A., M.D., O.T., Data Collection or Processing: E.Ö., D.D., I.K.A., M.D., O.T., Analysis or Interpretation: E.Ö., D.D., I.K.A., M.D., O.T., Literature Search: E.Ö., D.D., I.K.A., M.D., O.T., Writing: E.Ö., D.D., I.K.A., M.D., O.T.

Conflict of Interest: No conflict of interest was declared by the authors.

Financial Disclosure: The authors declared that this study received no financial support

\section{References}

1. Ramos-e-Silva M, Ramos-e-Silva S, Carneiro S: Acne in women. Br J Dermatol 2015;172(Suppl1):20-6.

2. Williams C, Layton AM: Persistent acne in women: Implications for the patient and for therapy. Am J Clin Dermatol 2006;7:281-90.

3. !!! INVALID CITATION !!!

4. Rotterdam ESHRE/ASRM-Sponsored PCOS Consensus Workshop Group. Revised 2003 consensus on diagnostic criteria and long-term health risks related to polycystic ovary syndrome. Fertil Steril 2004;81:19-25.

5. Wild RA, Vesely S, Beebe L, Whitsett T, Owen W: Ferriman Gallwey selfscoring I: performance assessment in women with polycystic ovary syndrome. J Clin Endocrinol Metab 2005;90:4112-4.

6. Whitaker L, Critchley HO: Abnormal uterine bleeding. Best Pract Res Clin Obstet Gynaecol 2016;34:54-65.

7. National Cholesterol Education Program (NCEP) Expert Panel on Detection Evaluation, and Treatment of High Blood Cholesterol in Adults (Adult Treatment Panel III). Third Report of the National Cholesterol Education Program (NCEP) Expert Panel on Detection, Evaluation, and Treatment of High Blood Cholesterol in Adults (Adult Treatment Panel III) final report. Circulation 2002;106:3143-421.

8. Matthews DR, Hosker JP, Rudenski AS, Naylor BA, Treacher DF, Turner RC: Homeostasis model assessment: insulin resistance and beta-cell function from fasting plasma glucose and insulin concentrations in man. Diabetologia 1985;28:412-9.

9. Goulden V, Clark SM, Cunliffe WJ: Post-adolescent acne: a review of clinical features. Br J Dermatol 1997;136:66-70.

10. Kligman AM: Postadolescent acne in women. Cutis 1991;48:75-7.

11. Maneschi F, Noto G, Pandolfo MC, Palisi F, Martorana A: Androgenic evaluation of women with late-onset or persistent acne. Minerva Ginecol 1989;41:99-103

12. Vexiau P, Husson C, Chivot M, Brerault JL, Fiet J, Julien R, et al: Androgen excess in women with acne alone compared with women with acne and/or hirsutism. J Invest Dermatol 1990;94:279-83.

13. Darley CR, Kirby JD, Besser GM, Munro DD, Edwards CR, Rees LH: Circulating testosterone, sex hormone binding globulin and prolactin in women with late onset or persistent acne vulgaris. Br J Dermatol 1982;106:517-22.

14. Slayden SM, Moran C, Sams WM, Jr, Boots LR, Azziz R: Hyperandrogenemia in patients presenting with acne. Fertil Steril 2001;75:889-92.

15. Chrousos GP, Peck GL, Gross EG, Cutler GB, Jr, Loriaux DL: Adrenal function in women with idiopathic acne. J Invest Dermatol 1982;78:468-71.

16. Thiboutot D, Gilliland K, Light J, Lookingbill D: Androgen metabolism in sebaceous glands from subjects with and without acne. Arch Dermatol 1999;135:1041-5.

17. Khunger N, Kumar C: A clinico-epidemiological study of adult acne: Is it different from adolescent acne? Indian J Dermatol Venereol Leprol 2012;78:335-41.

18. Sardana K, Bansal P, Sharma LK, Garga UC, Vats G: A study comparing the clinical and hormonal profile of late onset and persistent acne in adult females. Int J Dermatol 2020;59:428-33.

19. Chen W, Thiboutot $D$, Zouboulis CC: Cutaneous androgen metabolism: basic research and clinical perspectives. J Invest Dermatol 2002;119:992-1007.

20. Cinar N, Cetinozman F, Aksoy DY, Elcin G, Yildiz BO: Comparison of adrenocortical steroidogenesis in women with post-adolescent severe acne and polycystic ovary syndrome. J Eur Acad Dermatol Venereol 2015;29:875-80. 
21. Betti R, Bencini PL, Lodi A, Urbani CE, Chiarelli G, Crosti C: Incidence of polycystic ovaries in patients with late-onset or persistent acne: hormonal reports. Dermatologica 1990;181:109-111.

22. Geller L, Rosen J, Frankel A, Goldenberg G: Perimenstrual flare of adult acne. J Clin Aesthet Dermatol 2014;7:30-4.

23. Yang YS, Lim HK, Hong KK, Shin MK, Lee JW, Lee SW, et al: Cigarette smokeinduced interleukin-1 alpha may be involved in the pathogenesis of adult acne. Ann Dermatol 2014;26:11-6.

24. Balta I, Ekiz O, Ozuguz P, Ustun I, Karaca S, Dogruk Kacar S, et al: Insulin resistance in patients with post-adolescent acne. Int J Dermatol 2015;54:662

25. Romańska-Gocka K, Wozniak M, Kaczmarek-Skamira E, Zegarska B. Abnormal plasma lipids profile in women with post-adolescent acne. Postepy Dermatol Alergol 2018;35:605-8.

26. El-Akawi Z, Abdel-Latif N, Abdul-Razzak K, Al-Aboosi M: The relationship between blood lipids profile and acne. J Health Sci 2007;53:596-9.
27. Knaggs HE, Wood EJ, Rizer RL, Mills OH: Post-adolescent acne. Int J Cosmet Sci 2004;26:129-38

28. Juhl CR, Bergholdt HKM, Miller IM, Jemec GBE, Kanters JK, Ellervik C: Lactase persistence, milk intake, and adult acne: a mendelian randomization study of 20,416 danish adults. Nutrients 2018;10:1041.

29. George RM, Sridharan R: Factors aggravating or precipitating acne in indian adults: a hospital-based study of 110 cases. Indian J Dermatol 2018;63:328 31.

30. Till AE, Goulden V, Cunliffe WJ, Holland KT: The cutaneous microflora of adolescent, persistent and late-onset acne patients does not differ. $\mathrm{Br} J$ Dermatol 2000;142:885-92

31. Vergou T, Mantzou E, Tseke P, Moustou AE, Katsambas A, Alevizaki M, et al: Association of thyroid autoimmunity with acne in adult women. J Eur Acad Dermatol Venereol 2012:26:413-6. 